\title{
Assessment of Changes in Channel Morphology in a Mountain River Regulated Using Grade Control Structures
}

\author{
Joanna Korpak ${ }^{1}$ \\ 1 Faculty of Environmental and Power Engineering, Cracow University of Technology, Warszawska 24, \\ 31-155 Cracow, Poland \\ e-mail: joanna.korpak@pk.edu.pl
}

\begin{abstract}
Grade control structures (GCSs) serve as some of the most frequently used forms of river channel regulation in the Polish Carpathians. The main purpose of such structures is to reduce the gradient of the channel and strike a balance between erosion and deposition. Despite the widespread use of GCSs, not much is known about their functioning over the long term. The aim of the study was to examine a host of changes in channel morphology in a mountain river regulated using such structures. The object of the research was the lower stretch of Biały Dunajeca Carpathian river that follows a high mountain regime. The studied river stretch was regulated 33 years ago. The history of regulation and state of the channel immediately following regulation work were assessed using available regulation documents as well as a document on the post-construction period for the studied structures. The presentday morphology of the studied river channel was investigated via a geomorphologic survey and assessment of 22 channel cross sections. Gradual changes in morphology were analyzed using orthophotomaps from different years. Research has shown that the studied river channel is shaped by all fluvial processes. In the longitudinal profile, distinct channel zones characterized by stable tendencies were identified. The upstream zone is dominated by deposition, where the channel is flooded with debris after each high water stage, and GCSs cease to function as barriers to material transport. In the middle zone, lateral erosion plays a greater role, while in the downstream zone it is downcutting and lateral erosion. The river cuts alternately into both banks, thus damaging its regulated pathway. The role of deposition increases once again in the mouth zone of the river. The studied channel is not stable, and its morphology has changed many times over the years due to discharges much lower than design discharge. The Biały Dunajec did not conform to the parameters of its regulated pathway and aims to increase its width and sinuosity. The studied channel stretch requires ongoing financial expenditures to cover repair work.
\end{abstract}

Keywords: grade control structures, mountain river training, river channel processes

\section{INTRODUCTION}

The problem of downcutting affects river and stream channels in mountain areas in many parts of the world. This is due to three primary factors channel regulation leading to increased gradients and flow energy of rivers, extraction of channel debris, and changes in land use leading to reduction of surface runoff and material supply from hillslopes to channels [Korpak 2018, Wohl 2006].

One frequent response to excessive channel deepening has been regulation using GCSs. This form of regulation most often takes place in steep, eroded sections frequently found in the area downstream of dams that halt material transport [Korpak 2018]. While this is the most often encountered form of regulation in mountain rivers [Radecki-Pawlik 2003a], few studies have focused on its long-term effects. The main purpose of GCSs is to reduce channel gradient and produce a channel between drops that would provide for a balance between erosion and deposition [Galia et al. 2016, Galia and Škarpich 2017, Lenzi et al. 2003]. GCSs break the continuity of material transport [Martín-Vide and Andreatta 2009]. This may lead to the deepening or narrowing of the river channel, lack of debris sorting, lack of characteristic downstream fining of river sediments, as 
well as development of armor layer [Boix-Fayos et al. 2007, Korpak 2015]. Scouring zones are usually found immediately below GCSs [Gaudio et al. 2010, Lenzi et al. 2003]. Deposition is the predominant process upstream of GCSs, up to the point when sedimentary wedges become filled in [Galia et al. 2016]. In some cases, when the influx of material from upstream sections or riverbanks is large, the longitudinal profile becomes evened out and some transport capability is then restored, especially that of smaller grain sizes [Boix-Fayos et al. 2007]. However, river channels with a set of GCSs are frequently affected by a shortage of debris, thus deposition remains a lesser issue [Korpak 2015, 2018, Piton and Recking 2016].

According to the EU Framework Water Directive, traditional GCSs ought not be used, as they disrupt channel continuity [Korpak 2018]. Solutions to this problem are being sought. One option is to remove the GCSs and bank reinforcements [Wohl et al. 2015], while another is to transform the traditional concrete GCSs into hydraulic structures resembling natural rapids that also reduce channel gradients, but provide sufficient connectivity for sediment transport and aquatic organisms [Korpak et al. 2019, Lenzi 2002, Radecki-Pawlik 2013b]. Any decisions in this area should be preceded by studies on the long-term effects of GCSs on channel dynamics and morphology.

The purpose of the study was to assess changes in morphology of mountain river channel regulated with GCSs over the lifespan of these structures. A section of the Biały Dunajec River in the city of Nowy Targ was selected for study purposes. The GCSs in the city were built 33 years ago and the studied river does not have any tributaries along this stretch that would additionally affect channel morphology. The study sought to answer the following question: Have the city's GCSs fulfilled their mission and has the river channel become stable in this section?

\section{Study area}

The research was conducted on the Carpathian river Biały Dunajec, which originates in the Tatra Range and cuts across the following geomorphologic units of the Podhale region: Podtatrzański Trench, Gubałowskie Foothills, Pieniny Klippen Belt, Orawsko-Nowotarska Basin [Klimaszewski 1972]. The river is $35 \mathrm{~km}$ long and joins the larger
Dunajec River in the city of Nowy Targ at an elevation of 580 meters above sea level (Figure 1).

The studied catchment is characterized by variable geology. Crystalline rocks predominate in the Tatra Mts., while in the adjacent Podhale region, the following types of rocks are found: Podhalański flysch consisting of sandstone, shale with insetting agglomerate of the Zakopiańskie and Chochołowskie layers, limestone and marl in the Pieniny Klippen Belt, Magurski flysch (sandstone and shale).

Climate conditions in the catchment are highly variable due to the presence of five climate zones in the studied area. The mean annual temperature ranges from -0.8 on Kasprowy Wierch Mountain to 5.3 in the city of Nowy Targ, and the mean annual precipitation total ranges from $1,610 \mathrm{~mm}$ to $760 \mathrm{~mm}$ (respectively) [Hess 1965]. The Biały Dunajec features a high-mountain regime, with a quick flood wave build-up and very violent course of flood tide events. Among the crucial factors resulting with such effect are the climate, high proportion of the catchment located in high mountains, steep gradients, and the elongated shape of the catchment.

The studied downstream section of river is $3.28 \mathrm{~km}$ long and is located in the city of Nowy Targ found in the Orawsko-Nowotarska Basin in southern Poland. The studied section was regulated using 12 concrete GCSs. The largest debris grain size observed along this section of river was about $30 \mathrm{~cm}$, while most pieces of debris found here had a diameter of about $10 \mathrm{~cm}$. The closest water level gauging site is located in the town of Szaflary at the $7.23 \mathrm{~km}$ of the river. Mean annual discharge over the long term equaled $5.7 \mathrm{~m}^{3} / \mathrm{s}$ [Project No. 2064]. The largest flood in the years 1983-2019 occurred in 1997 (Figure 2). This flood nearly equaled 100-year flood (Q100). Floods greater than the Q2 (2-year recurrence interval flood) occurred 21 times in the studied area. Only the flood of 2018 was greater than Q5. An increase in the frequency of flooding has been observed in recent years in the study area.

There are no significant tributaries between the studied section of river and the water gauging site in Szaflary. The size of the catchment area also does not increase significantly. Hence, it may be assumed that the time of occurrence and probability of exceeding a flood are similar for both locations. 


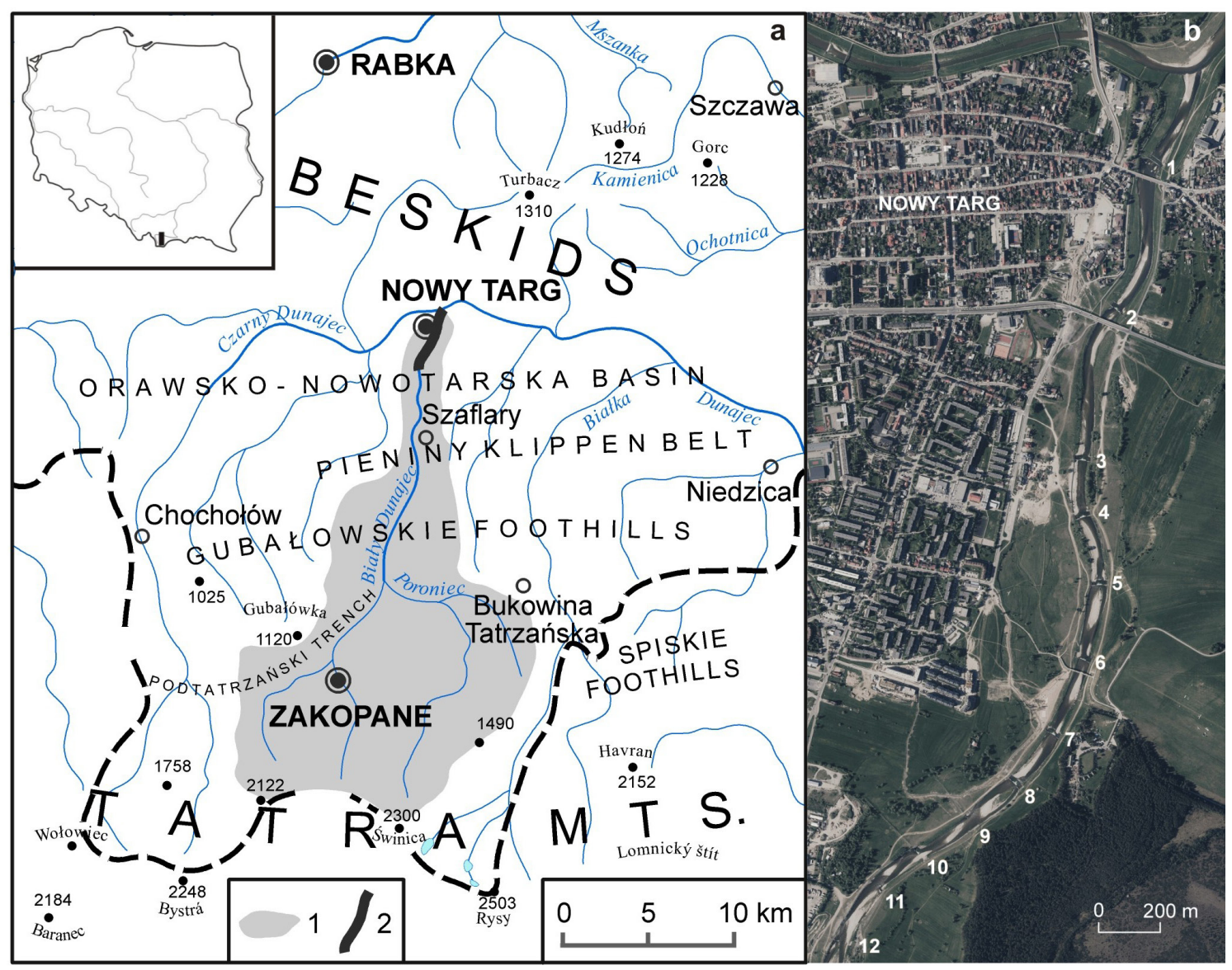

Figure 1. Study area: a - location of the Biały Dunajec catchment: 1 - Biały Dunajec catchment, 2 - studied river section, $\mathrm{b}$ - studied river section with grade control structures and their numbers

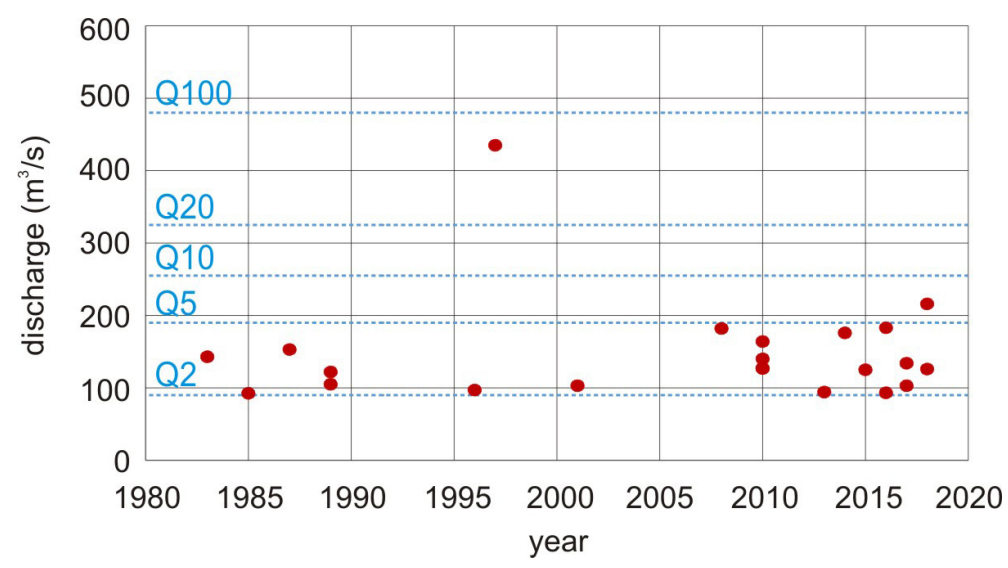

Figure 2. Flood events with a recurrence interval greater than 2 years in the Biały Dunajec catchment in the years 1983-2019

\section{Research methods}

The course of regulation works and the state of the studied river channel immediately following the completion of works were examined thanks to the availability of archival materials at Cracow's Regional Water Management Authority.
Technical documentation from 1977 and 1984 as well as a document on the post-regulation review of the river from 1987 were obtained. The abovementioned documents consisted of a descriptive part and a diagrammatic part: maps, longitudinal profiles, and cross sections of the studied river channel. 
Orthophotomaps from 2003, 2009, 2015, and 2018 were used to recreate gradual changes in the studied channel's morphology. These data were then used to determine the number and area of bars and length of reaches affected by riverbank erosion. In order for these data to be comparable for different reaches, they were recalculated per 100 meters of channel length. The active channel width was measured on the 2018 orthophotomap. An active stream channel was defined as a wetted low-flow channel and gravel bars without any vegetation or with patches of young vegetation [Hajdukiewicz and Wyżga 2019]. Channel width was measured every 40 meters perpendicular to the channel axis. Both the maximum and minimum width was also measured. The error caused by uncertainty associated with the difficulty of identifying the shoreline at some locations (effect of shade created by riverbank vegetation) was estimated to be in the range from 0 to 5 meters.

Present-day river channel morphology was assessed during fieldwork conducted in September 2019. Fieldwork consisted of channel surveys as well as the geodetic measurement of GCSs and overall regulation pathway. The location and size of all fluvial forms were also assessed in the process. The state of concrete GCSs and riverbank scarps was examined as well. Tape and a GPS device were used in the course of the fieldwork. A total of 21 cross sections of the river channel were created at the same sites as in 1986 and 1987. This made it possible to perform a comparative analysis of the shape and size of the studied channel after 33 years of the functioning of GCSs.

All observations and changes in the studied river channel were noted for each section between each GCS. The sections examined in the study are numbered analogically to GCS numbers - from 12 at $\mathrm{km} 3.280$ to 1 at $\mathrm{km} 0.407$. Therefore, section 6-5 implies the section between GCS no. 6 and 5.

\section{River regulation along the Biały Dunajec using grade control structures}

The Biały Dunajec leaves the Pieniny Klippen Belt and enters the flat Orawsko-Nowotarska Basin resulting in a dramatic decrease in gradient and flow energy. Under natural conditions, up until the late 1960s the, the river followed a braided course in the Orawsko-Nowotarska Basin and its channel was as wide as 400 meters [Korpak 2018]. Regulation works were performed in the second half of the $20^{\text {th }}$ century, which changed the nature of this section of river. Two weirs were constructed - one at $\mathrm{km} 6.245$ before the year 1970 and another at $\mathrm{km} 5.482$ in the year 2000 . In 1971 groins were constructed downstream of the weirs between $\mathrm{km} 5.101$ and 2.192, which led to a narrowing of the channel to 30 meters. The large channel gradient and shortage of sediment (trapped upstream of the weirs) led to the deepening of the channel in the section with groins. The channel became 1 to 2 meters deeper within a period of 6 years [Kościelniak 2004, Korpak 2018]. The channel downstream of section with groins also became deeper resulting in a gradual loss of stability of local bridges and riverbank reinforcements. However, the river here still maintained its multi-channel flow path, and continued to deposit large amounts of material during flood events, thus creating additional flood risk [Kościelniak 2004].

The downstream section of the channel was regulated in the late $1970 \mathrm{~s}-$ from $\mathrm{km} 0.000$ to $\mathrm{km}$ 3.280 - using GCSs. The purpose of the regulation was to stabilize the wide, braided river channel and reduce its gradient from 0.0082 to 0.004 [Project No. 101]. The land recovered by the regulation process along the river was supposed to be used for new development purposes. The regulation work included the shaping of a new river channel and placement of 11 concrete GCSs with drop height of 1 meter. The $12^{\text {th }}$ one-meter-high GCS, located closest to the mouth of the river, had already been built in 1975 [Project No. 2220]. The width of the regulated channel was 50 meters. The cross-section of the channelbed and GCS's crests were designed to suit different water levels. The middle pathway was the lowest, horizontal, and had a width of 20 meters. Its purpose was to concentrate water flow at low water stages. Two parallel flow pathways were 15 meters wide and had a gradient of $4 \%$ (Photo 1a). The depth of stilling basins equaled 0.8 meters. The overall plan was to establish vegetation on the scarps of the riverbanks. GCSs were constructed sequentially in the direction of the mouth of the river over the period 1979-1986 (numbered from 12 to 2). By 1984 only 5 of 11 planned GCSs had been built and these were already damaged. In the course of a flood in 1983 the river bypassed its regulated channel and flowed down its old channel. An inspection of ongoing work was conducted at the time that revealed that many tasks had been completed not according to plan [Project 
No. 4260]. Problems linked with the work effort included incorrect placement of DCSs (differences up to $31 \mathrm{~m}$ ) and incorrect drop heights (differences up to $0.38 \mathrm{~m}$ ). Instead of the planned gradient between GCSs of 0.004 , the actual gradients varied from 0.0026 to 0.0092 . Inspectors also found problems with the process used to manufacture the concrete and concrete elements used in the project. The plan to establish vegetation on riverbank scarps was abandoned. In order to improve the condition of existing GCSs and prevent damage in the future, a longitudinal dike was designed and then constructed in 1984. The role of it was to direct water towards the crest of GCS no. 12. Vegetation on scarps was also introduced at the time [Project No. 152].

\section{Present-day morphology of the studied channel section}

Repair works were conducted during the fieldwork stage in September 2019 in the section with GCSs. Major changes did occur in the long section 6-3, where riverbanks were newly created and reinforced (Photo $1 \mathrm{~b}$ ). Denudation forms present in this section were formed artificially and contained material from the riverbank readjustment process.

A small number of small bars were noticed across the studied part of the river channel. The number of bars per 100 meters of channel length never exceeded 2 and generally declined towards the mouth section of the river (Figure 3a). The bars were usually small in the upstream part of the study area (Section 12-10). However, one bar with a very large area was identified in the mouth section. The largest number of cutbanks were noted between GCS no. 10 and 7 as well as in the mouth section (Figure 3b). New reinforcements in the form of rip-rap was also noted (Figure 3b). Some of them were constructed in the course of repair work, while some may have been several years old. The remaining parts of the channel featured old reinforcements constructed
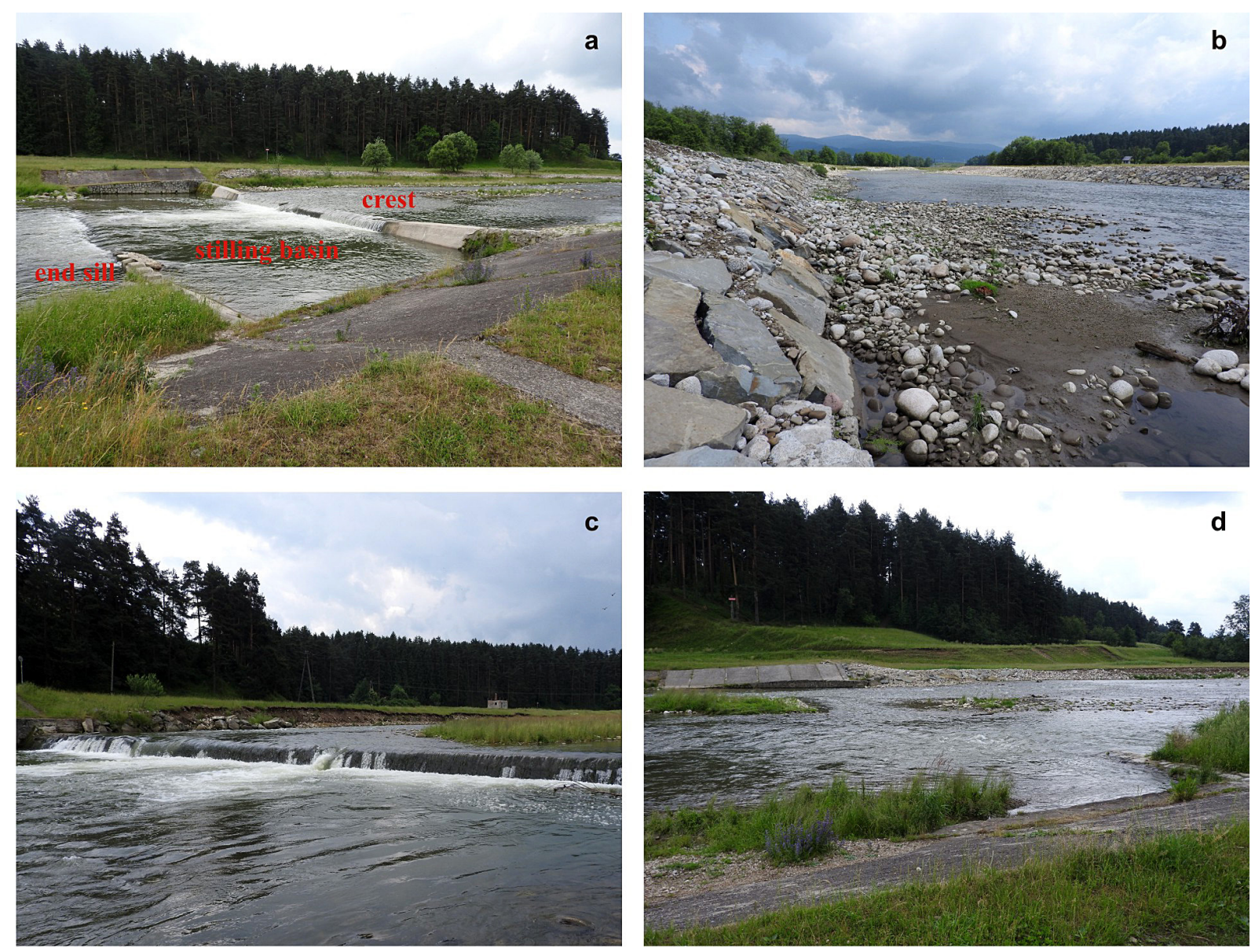

Photo 1. Channel section with grade control structures on the Biały Dunajec in the city of Nowy Targ: a - GCS, $\mathrm{b}$ - recreated and newly reinforced riverbank, c - damaged bank reinforcement and partly eroded GCS's crest, $\mathrm{d}$ - GCS covered with debris 
a

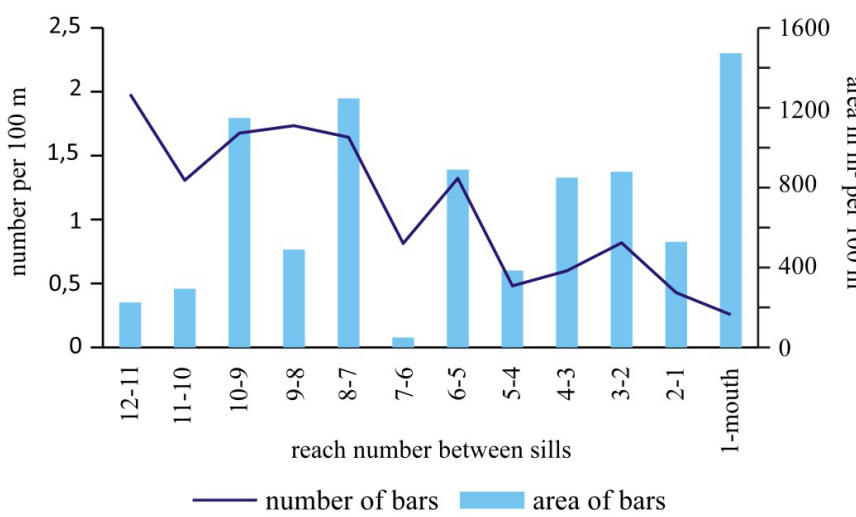

b

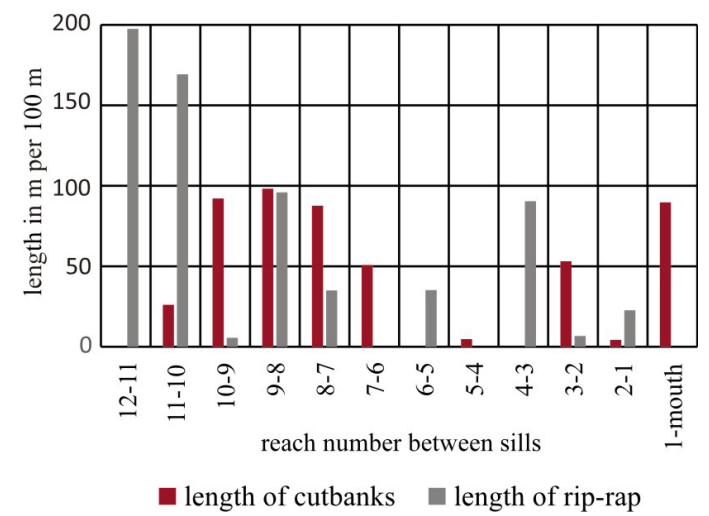

Figure 3. Fluvial forms and riverbank reinforcements recorded in the course of field surveys in 2019: a - number and area of bars, $\mathrm{b}$ - length of cutbanks and new bank reinforcements; all values are expressed per $100 \mathrm{~m}$ of channel length

in the course of regulation work. In many places the reinforcements were damaged and partly washed away (Photo 1c). In sections 10-9, 8-6, and 2-1 high bars covered with vegetation were noted along the left bank of the river. They were higher than the remaining bars, but lower than the floodplain. Cutbanks or reinforcements were found on opposing banks. Such a situation proves downcutting and a tendency of the channel to lateral migration.

GCS no. 9 was fully covered with debris. Its crest included a central bar (Photo 1d). Most GCSs had partly deteriorated crests and end sills downstream of stilling basins (Photo 1c).

\section{Changes in river channel morphology in the years 1986-2018}

In November of 1987 a post-regulation survey was conducted of the new GCSs [Project No. 4170]. The purpose of the survey was to check the level of functionality of these structures following a larger flood in May of 1987. The survey revealed significant damage to each GCS and the regulation pathway in itself (Table 1). In section 12-9 the stilling basins and end sills were covered with debris. New bars formed throughout the entire channel, especially near convex riverbanks.
Lateral erosion was noted everywhere except section 8-7. Downcutting was identified in the area downstream of GCS no. 7. Scours 60 to $80 \mathrm{~cm}$ deep were also noted here. All damaged elements in the area were repaired.

Analysis of aerial photos from 2003, 2009, 2015, and 2018 showed further changes in the morphology of the studied channel as well as changes in the condition of GDSs. Each aerial photo shows the condition of the channel at different times after the passage of a flood wave exceeding Q2. The smallest time interval since the time of the event was 2 months (2015), while the largest 1.5 years (2003).

Stilling basins and end sills of GCSs no. 12-9 were covered with debris in each photo. In some cases, the debris also covered crests (GCS no. 12 in each examined photo, GCS no. 11 in 2003 and 2018, GCS no. 10 in 2018, GCS no. 9 in 2009, 2015, and 2018). In 2018 coverage with debris also affected stilling basins and end sills in the case of GCSs no. 7-4.

The number and size of forms found on the examined photos are similar (Table 2). The largest number of bars were noted in 2015 - a short time after a flood. The largest length of cutbanks was noted in 2009, with declines in subsequent years. This was due to reinforcement work on

Table 1. Damage to GCSs and the regulation pathway after a flood in 1987 [Project No. 4170]

\begin{tabular}{|l|c|c|c|}
\hline \multicolumn{1}{|c|}{ Type of damage to GCSs } & GCS no. & $\begin{array}{c}\text { Changes in regulation } \\
\text { pathway }\end{array}$ & Section no. \\
\hline Damage to bank reinforcements above crest & 12,2 & Left bank erosion & $12-10,6-2$ \\
\hline Debris coverage of stilling basin and end sill & $12,11,9,2$ & Right bank erosion & $\begin{array}{c}12-11,10-8,7-6,5-4, \\
3-2\end{array}$ \\
\hline Damage to bank reinforcements below end sill & $8,7,4,2$ & Bed erosion, scours & $7-2$ \\
\hline Scour below end sill & $7,6,5,4,3$ & Debris deposition & $12-9,8-2$ \\
\hline
\end{tabular}


Table 2. Fluvial forms observed on aerial photos along the studied length of the river

\begin{tabular}{|c|c|c|c|}
\hline $\begin{array}{c}\text { Year photo } \\
\text { was taken }\end{array}$ & $\begin{array}{c}\text { Number } \\
\text { of bars }\end{array}$ & $\begin{array}{c}\text { Area of } \\
\text { bars }\left(\mathrm{m}^{2}\right)\end{array}$ & $\begin{array}{c}\text { Length of } \\
\text { cutbanks }(\mathrm{m})\end{array}$ \\
\hline 2003 & 42 & 36252 & 2521 \\
\hline 2009 & 33 & 32988 & 2639 \\
\hline 2015 & 51 & 46824 & 1983 \\
\hline 2018 & 38 & 46778 & 1893 \\
\hline
\end{tabular}

the riverbanks whose effects may be observed in aerial photos from 2015 and 2018.

A comparison of the number and size of forms observed on the aerial photos of each section does not reveal any clear patterns. The evolution of a given section at a given point in time may be affected by a variety of natural and anthropogenic factors. The dimensions of the forms found on photos from different years depend on the water level on the day the photo was taken. To avoid at least some errors in the process of drawing conclusions, the number and size of forms noted for each given channel section for subsequent years were added together. It was assumed that this will make it possible to at least identify larger differences in the morphology of sections between each studied GCS.

Research has shown that the largest number of bars formed in river sections $11-10$ and $9-8$ as well as between GCS no. 2 and the mouth of the river. The largest area occupied by bars was noted in sections $12-11$ and 5-4 (Figures $4 a, c$ ). The role of deposition was found to be least important in sections 8 to 5 . The largest number of central bars, which suggests braiding tendency, were observed in section 9-8 (Figure 4b). In addition, channel sections $11-10$ as well as those between GCS no. 2 and the mouth of the river were characterized by the presence of a large number of central bars. The number of cutbanks tended to decrease towards the mouth of the river (Figure 4d) - their largest number was observed in section 9-8, while large declines were observed downstream of GCS no. 4. Section 7-6 was affected by some lateral erosion, as observed on photographs up to 2009 , with no undercuts noted on photographs from 2015 and 2018. Narrow lateral bars covered with vegetation were identified, on all the studied photos, along the left bank in channel sections $8-6$ and $2-1$. Similar forms were also found along the left bank in section 10-9 in 2015 and 2018. Vegetated central bars were also observed in section 4-3 in 2009 and 2015. The presence of these forms implies the presence of downcutting.
The initially uniform width of the regulated channel became highly variable (Figure 5). The mean width of the channel was 45.7 meters, according to an orthophotomap from 2018, ranging from $41.4 \mathrm{~m}$ in section $3-2$ to $62.6 \mathrm{~m}$ in section 9-8 (section with largest number of undercuts). The largest differences in width were noted for the section from GCS no. 2 to the mouth of the river as well as sections $6-5$ and $9-8$. The most highly uniform channel width was observed for sections 11-10 and 8-6. In the first case, the cause of this was riverbank reinforcements. In the second case, it was the occurrence of high, vegetated lateral bars narrowing the profile of the river channel.

A side-by-side comparison of bars and cutbanks from all the aerial photos revealed main areas of deposition and lateral erosion that functioned during the study period (Figure 6a). It turns out that the location of the largest bars and cutbanks is similar from year to year. This does not apply to sections 12 to 8 , where bars formed at multiple locations and both riverbanks were undercut. In subsequent sections one may easily observe a tendency of concave riverbank erosion as well as deposition under convex riverbanks. In the case of straight sections, such as section 6-5, central bars form and both riverbanks become eroded. Hence, the right bank of section $8-7$ is eroded, left bank of section 7-6 is eroded (short segment downstream of GCS no. 7), right bank of section 5-4, left bank of section 4-3, first the right bank and then the left bank of section 3-2, and finally right bank of section $2-1$. In the section between GCS no. 1 and the mouth, both riverbanks are eroded, but bars form mainly close to the right bank and right at the mouth of the studied river.

This prompts the following question: What is the scale of observed changes over the course of the entire study period? The answer to this question is provided by an analysis of cross sections for the years 1986 (immediately after regulation work), 1987 (after first major flood), and 2019 (after 33 years of the functioning of GCSs) made for the same locations along the studied channel (Figure 6). It is important to remember that measurements collected in 2019 were performed right after repair work on the channel of section 6-3 (Figure 6c).

Larger stretches of the studied river channel became somewhat deeper after a flood in 1987 and then again after 33 years since the onset of river regulation work (Table 3). The channel 


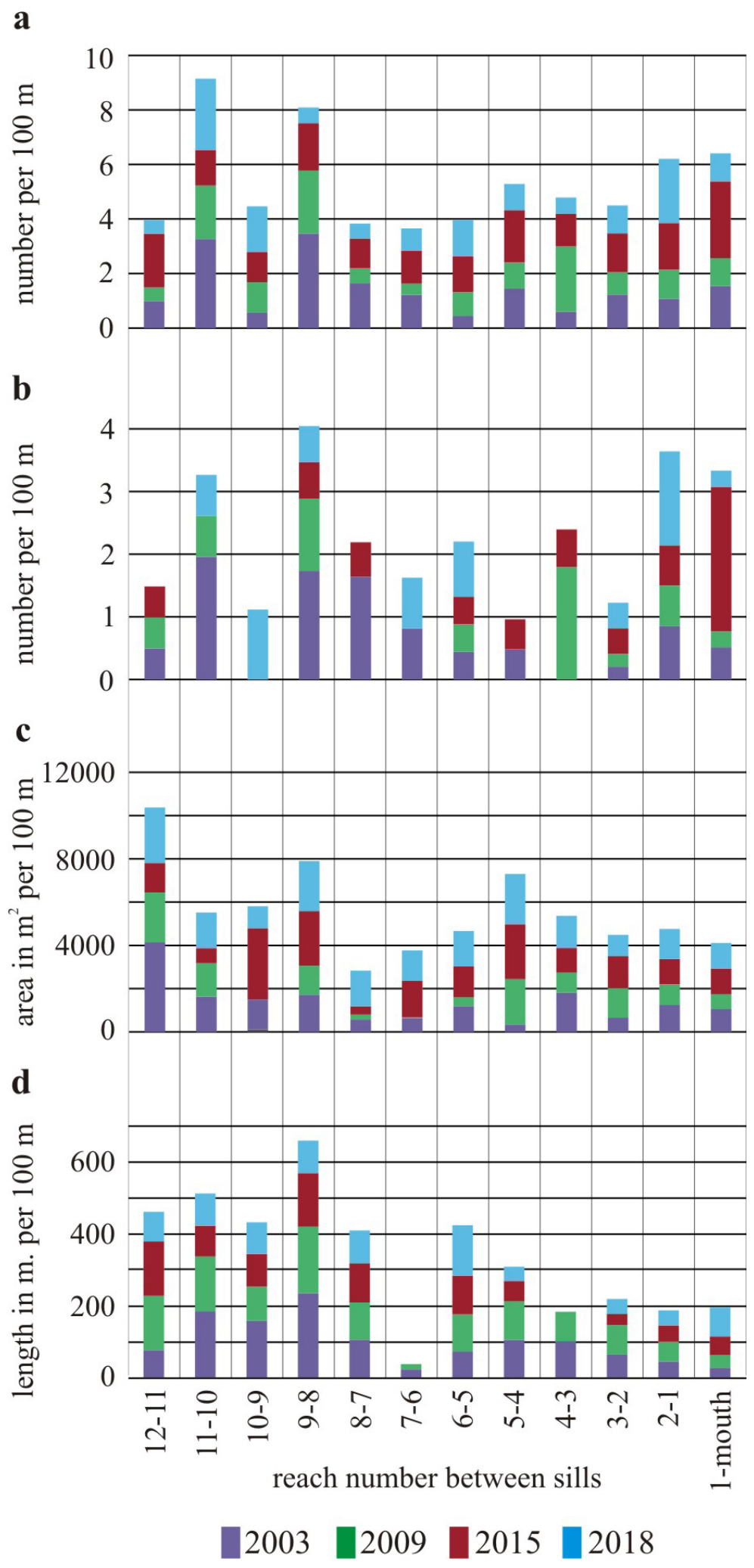

Figure 4. Fluvial forms observed on aerial photos from 2003, 2009, 2015, and 2018: a - number of bars, $\mathrm{b}$ - number of central bars, $\mathrm{c}$ - area of bars, $\mathrm{d}$ - length of cutbanks; all values are expressed per $100 \mathrm{~m}$ of channel length

became $21 \mathrm{~cm}$ deeper, on average, in the years 1986-1987, and $25 \mathrm{~cm}$ deeper, on average, in the years 1986-2019. The maximum increase in depth exceeded one meter. Downcutting occurs mainly in the upstream section of the studied channel between GCSs no. 12 and 10 as well as from the halfway point between GCSs no. 7 and 6 and the mouth of the river. The greatest degree of 


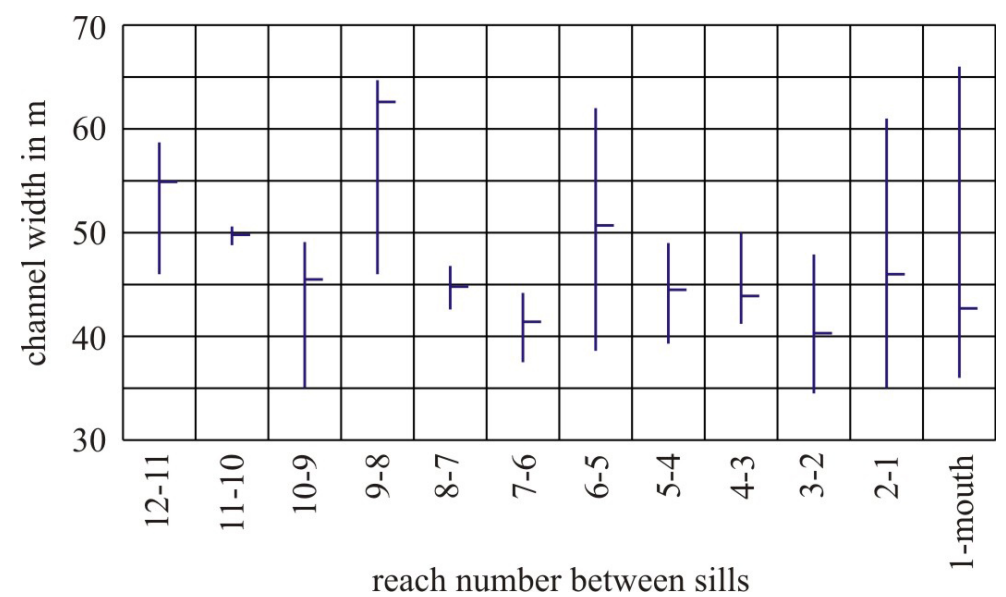

Figure 5. Width of river channel in sections between each GCS, measured on an orthophotomap from 2018

erosion was noted in section 4-3. Its increase in channel depth in the years 1986-1987 reached a maximum of $73 \mathrm{~cm}$ (Figure 6b). However, in later years some deposition was observed. The largest increase in channel depth in each studied year is noted at the same location - most frequently under one riverbank. The largest deposition occurs in section 9-8, where the height of the channel bed increased by an average of $41 \mathrm{~cm}$ in the years 1986-1987; however, a small decrease has been observed in 2019 (Figure 6d). Vertical stability was observed in sections 10-9 and 8-6 (Figure 6e). Analysis of horizontal changes associated with lateral erosion showed that the displacement of a riverbank, triggered by a single flood event, may be as large as approximately 10 meters. However, many repair works have been performed in the years since, and the location of riverbanks in the studied channel is now similar to that in 1986. The maximum shift of the channel bank is approximately $11 \mathrm{~m}$ above GCS no. 8 .

Geodesic measurements of GCSs were performed in 1986 and 2019. In some cases (GCSs no. 12 and 3 in 1987 and GCS no. 9 in 2019) it was not possible to determine the level of crest or end sill due to coverage by debris. GCS no. 1 was not measured in 1986 . The measurements showed changes suggesting major damage to GCSs (Table 4). Crests and, to an even greater extent, end sills of the GCSs, were found to be lower than before. In effect, the height of most GCSs (measured in terms of the difference between the level of the crest and the end sill) is higher today than that in 1986. The largest increase in GCS height was that for GCSs no. 7 and 6 (increase of more than $30 \mathrm{~cm}$ ). Changes in GCS heights affect the equilibrium slope, measured as a ratio of the difference of the end sill level of a given GCS and the crest level of GCS located further downstream and the distance between the end sill and crest. In most cases the equilibrium slopes have become smaller over time. Only the slope between GCSs no. 10 and 9 did increase during the studied period of time.

\section{Functioning of river channel with grade control structures in the years 1986-2019}

The studied section of channel is not stable after 33 years of the functioning of GCSs. A comparison of the state of the channel in 1986 and 2019 shows that changes occurring in the studied channel are not large. However, an analysis of changes in the morphology of the channel in the years in-between has shown that the channel has experienced multiple transformations over the study period. Floods were followed by repair work - the signs of which may be observed on aerial photos. However, its extent and exact date cannot be determined at this point in time. Moreover, it is not possible to accurately determine the scale and rate of change in the channel for any given year. What is known is the type of processes predominant along the studied river stretch and the main channel changes.

Sections 12-9 were characterized by large gradients and are affected by all fluvial processes. They are buried under debris during flood events. The source of this debris is the alluvial section located immediately upstream of the studied river section. The debris is deposited also on the crests as well as in stilling basins and on the end sills of GCSs. Therefore, GCSs no longer play the role of barrier to the transport of material, which is deposited chaotically, and bar locations change following each flood event. At the same time, this 


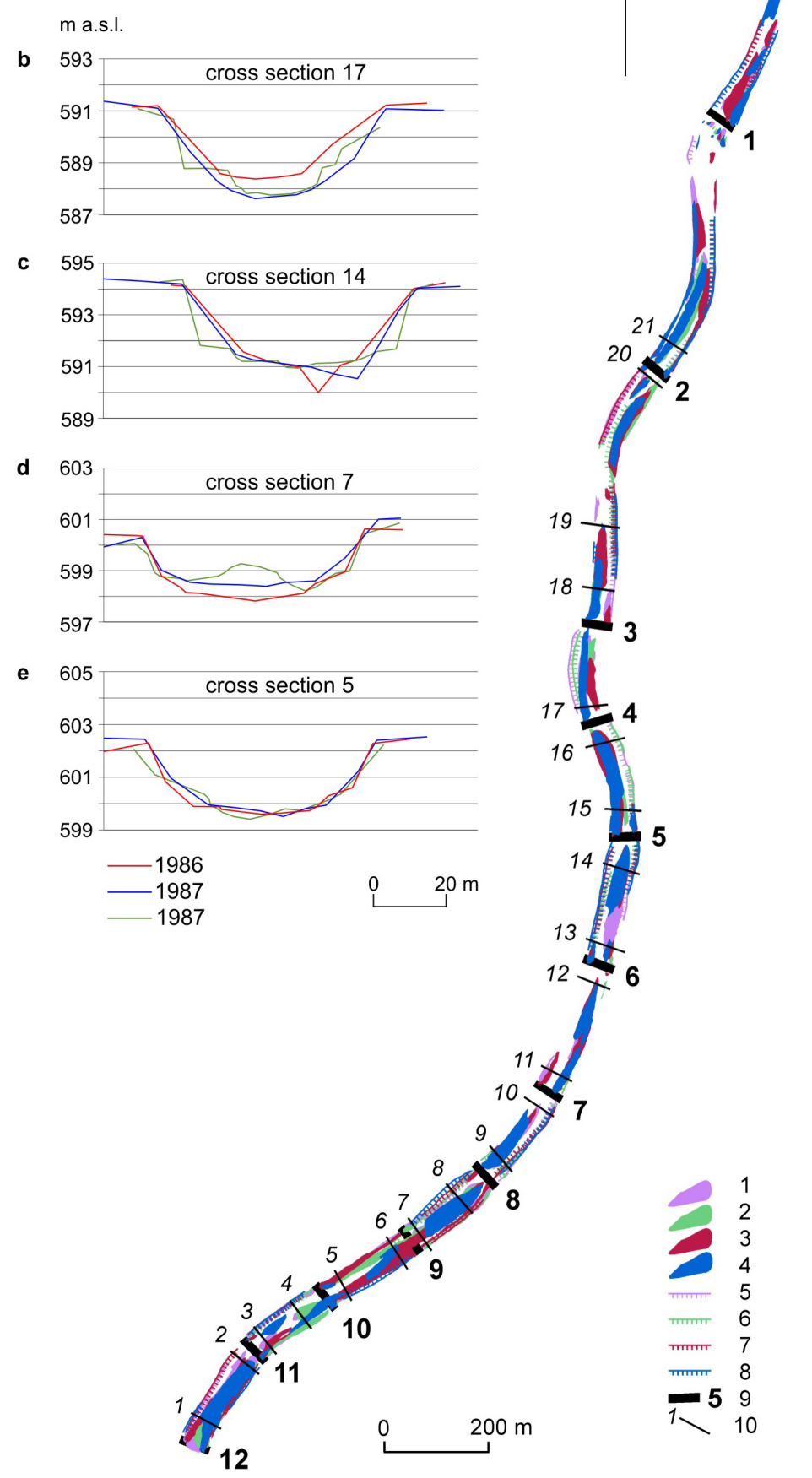

Figure 6. The changes of river channel morphology: a - location of bars and cutbanks in the years 2003, 2009, 2015 and 2018: 1-4 - bars present in the following years: 2003, 2009, 2015, 2018, 5-8 - cutbanks present in the following years: 2003, 2009, 2015, 2018, 9 - GCSs with their numbers, 10 - cross sections with their numbers; b-e - cross sections of the channel in years 1986, 1987 and 2019: b - in the section with downcutting, $\mathrm{c}-$ in the section recreated and newly reinforced in $2019, \mathrm{~d}$ - in the section with deposition, $\mathrm{e}-$ in the stable section

section experiences intense lateral erosion. While its banks are reinforced, these reinforcements are constantly being washed away and then repaired. Dowcutting is also active in this channel section, as shown by the lowering of the bed level relative to those in 1986 as well as by the erosion of GCSs. Section 9-8 is atypical, as shown by every available analysis of it. GCS no. 9 has largely ceased to exist, with its crest at the same level as the channel bed. Relative to other sections, this section features the largest number of bars (including central bars) and cutbanks. Its width is also the most variable. The first part of this section is dominated by deposition and the second 
Table 3. River channel cross section data for the years 1986, 1987, and 2019

\begin{tabular}{|c|c|c|c|c|c|c|c|c|}
\hline \multirow{2}{*}{$\begin{array}{c}\text { Cross section number } \\
\text { (channel reach) }\end{array}$} & \multicolumn{3}{|c|}{$\begin{array}{c}\text { Minimum elevation of stream bed } \\
\text { (m a.s.I) }\end{array}$} & \multicolumn{2}{c|}{$\begin{array}{c}\text { Average thickness of } \\
\text { sediment layer }(\mathrm{m})\end{array}$} & \multicolumn{3}{c|}{ Channel width at Q2 } \\
\cline { 2 - 9 } & 1986 & 1987 & 2019 & $1986-1987$ & $1986-2019$ & 1986 & 1987 & 2019 \\
\hline $1(12-11)$ & 602.67 & 602.65 & 602.32 & -0.02 & -0.36 & 50 & 54 & 57 \\
\hline $2(12-11)$ & 601.81 & 601.61 & 601.37 & -0.18 & -0.29 & 51 & 50 & 52 \\
\hline $3(11-10)$ & 601.35 & 600.95 & 600.88 & -0.02 & -0.26 & 54 & 50 & 53 \\
\hline $4(11-10)$ & 600.12 & 600.25 & 600.18 & 0.18 & -0.19 & 46 & 38 & 50 \\
\hline $5(10-9)$ & 599.60 & 599.51 & 599.41 & 0.12 & 0.07 & 52 & 48 & 51 \\
\hline $6(10-9)$ & 598.76 & 598.58 & 598.77 & 0.12 & -0.14 & 53 & 49 & 60 \\
\hline $7(9-8)$ & 597.82 & 598.39 & 598.22 & 0.41 & 0.34 & 51 & 47 & 53 \\
\hline $8(9-8)$ & 597.4 & 597.02 & 597.07 & 0.26 & -0.37 & 49 & 50 & 60 \\
\hline $9(8-7)$ & 595.41 & 595.41 & 595.7 & 0.21 & 0.25 & 43 & 41 & 42 \\
\hline $10(8-7)$ & 595.2 & 594.83 & 594.93 & -0.05 & -0.32 & 50 & 48 & 54 \\
\hline $11(7-6)$ & 593.25 & 593.16 & 593.42 & 0.05 & 0.25 & 38 & 44 & 36 \\
\hline $12(7-6)$ & 593.02 & 592.86 & 592.59 & -0.21 & -0.14 & 45 & 46 & 46 \\
\hline $13(6-5)$ & 592.1 & 591.19 & 592.33 & -0.38 & -0.07 & 40 & 51 & 48 \\
\hline $14(6-5)$ & 591.22 & 590.97 & 590.94 & -0.16 & -0.45 & 45 & 48 & 55 \\
\hline $15(5-4)$ & 589.79 & 588.89 & 589.72 & -0.15 & -0.03 & 43 & 43 & 41 \\
\hline $16(5-4)$ & 589.28 & 589.14 & 588.68 & -0.24 & -0.22 & 45 & 49 & 49 \\
\hline $17(4-3)$ & 588.38 & 587.62 & 587.76 & -0.73 & -0.60 & 38 & 48 & 46 \\
\hline $18(3-2)$ & 586.91 & 585.97 & 585.84 & -0.46 & -0.45 & 44 & 52 & 50 \\
\hline $19(3-2)$ & 586.05 & 585.89 & 585.99 & -0.12 & -0.03 & 48 & 48 & 46 \\
\hline $20(3-2)$ & 584.65 & 584.26 & 583.84 & -0.43 & -0.25 & 47 & 52 & 50 \\
\hline $21(2-1)$ & 583.82 & 583.82 & 583.14 & -0.02 & -0.12 & 49 & 51 & 50 \\
\hline & & & & & & & \\
\hline
\end{tabular}

Table 4. Changes in GCS height and equilibrium slope out between GCSs in the years 1986-2019

\begin{tabular}{|c|c|c|c|c|c|c|c|}
\hline \multirow{2}{*}{$\begin{array}{c}\text { GCS } \\
\text { number }\end{array}$} & \multicolumn{2}{|c|}{ GCS height $(\mathrm{m})$} & \multirow{2}{*}{$\begin{array}{c}\text { Difference in } \\
\text { GCS height }(\mathrm{m})\end{array}$} & \multirow{2}{*}{$\begin{array}{c}\text { Section between } \\
\text { GCSs }\end{array}$} & \multicolumn{2}{|c|}{ Equilibrium slope } & \multirow{2}{*}{$\begin{array}{l}\text { Difference in } \\
\text { slope }\end{array}$} \\
\hline & 1986 & 2019 & & & 1986 & 2019 & \\
\hline 12 & & 0.67 & & & & & \\
\hline 11 & 0.52 & 0.73 & 0.21 & $12-11$ & & 0.0045 & \\
\hline 10 & 0.57 & 0.4 & -0.17 & $11-10$ & 0.0069 & 0.0056 & -0.0013 \\
\hline 9 & 0.99 & & & $10-9$ & 0.0041 & 0.0070 & 0.0028 \\
\hline 8 & 0.78 & 0.93 & 0.15 & $9-8$ & 0.0036 & & \\
\hline 7 & 0.91 & 1.23 & 0.32 & $8-7$ & 0.0071 & 0.0064 & -0.0007 \\
\hline 6 & 0.84 & 1.21 & 0.37 & $7-6$ & 0.0054 & 0.0040 & -0.0014 \\
\hline 5 & 0.87 & 0.88 & 0.01 & $6-5$ & 0.0049 & 0.0031 & -0.0017 \\
\hline 4 & 0.85 & 0.96 & 0.108 & $5-4$ & 0.0041 & 0.0038 & -0.0003 \\
\hline 3 & & 1.02 & & $4-3$ & 0.0043 & 0.0046 & 0.0003 \\
\hline 2 & 0.69 & 0.67 & -0.022 & $3-2$ & & 0.0039 & \\
\hline 1 & & 0.88 & & $2-1$ & & 0.0043 & \\
\hline
\end{tabular}

section by lateral erosion and downcutting. It appears that the transport and deposition of material originating in the upstream portion of the channel end in this section.

GCSs located in sections 8 to 2 are not buried by debris, while deposition plays a secondary role. With the exception of section $8-7$, the channel gradient here is smaller than in sections found upstream. It appears that the dominant process here is erosion - primarily lateral erosion, but also downcutting. The tendency to lateral channel migration is quite apparent, as manifested in the form of permanent, high, vegetated bars found underneath one riverbank and pushing water underneath the opposite riverbank. Erosion affects the left bank and right bank in an alternating fashion. Bars are found along convex riverbanks and are most likely formed of material originating in riverbank erosion. Downcutting plays a greater role downstream of GCS no. 4, as shown by the smaller number of cutbanks and the presence of high, vegetated central bars. Section $7-6$ was 
found to be the most stable of the studied river channel sections.

Deposition once again plays a greater role downstream of GCS no. 2. The much larger Dunajec River certainly must play a role in the morphology and functioning of the mouth section of the studied river channel.

It must be emphasized that the processes described herein occur at relatively low discharges. In the study period only one flood event was noted with an occurrence interval of 10 years (Figure 2). At the same time, the river regulation project used to construct studied GCSs assumed the durability of regulated pathway up to Q10 as well as a lack of damage to the GCSs at discharges less than Q20 [Project No. 4260]. Yet, in reality, the GCSs of interest did not meet project expectations. Certainly, one of the reasons for this is the already mentioned negligence in the performance of regulation works. It also appears that one fundamental error was complete ignorance of the river's natural tendencies in this section of channel. A wide, multi-channel river was redirected into a narrow, straight regulation pathway. In order to identify other reasons for the failure of the regulation project, additional research is needed in the area of hydraulic conditions in the channel and the debris transport mechanism.

\section{DISCUSSION}

The evolution of the studied section of the Biały Dunajec River, after the period of regulation, occurred under atypical and variable debris influx conditions. First, the studied section was characterized by low material influx - both limited from the upstream channel sections by weirs and from the banks reinforced with groins. When amount of bedload in river is small, the continuity of material transport is interrupted, and channel sections between GCSs start to function independently of one another [Fryirs 2013, Galia and Škarpich 2017]. The river erodes the channel bed, leading in some cases to exposure of bedrock [Korpak 2015]. The greatest problem with erosion occurs immediately below GCSs, the greater the less material supply [Marion et al. 2006]. In addition, cases of GCS erosion and uneven GCS lowering have also been noted [Galia et al. 2016]. The Biały Dunajec river channel experienced significant erosion already after the first flood event that occurred just a year after the end of regulation work. Interestingly enough, maximum discharge during that flood event did not exceed Q5; hence, theoretically, no damage should have occurred. However, at the same time, deposition was observed in the upstream section of the grade control system. Already then, there must have been some supply of material from the upper section with groins,as this section experienced a gradual erosion since 1971 [Kościelniak 2004]. The rate of material influx increased significantly after a flood in 1997 when all groins were destroyed, riverbank material was released, and this section of river channel widened from 30 to more than $85 \mathrm{~m}$ [Kościelniak 2004]. Since that time period, deposition is the predominant process in the upstream section of the studied grade control system. Overall, GCSs no longer serve as a barrier to transport of not only fine fractions, but the entire cover. Similar cases of partial or complete burial of GCSs were observed in the case of sudden sediment release, e.g. as a result of landslide activation on hillslopes or as a result of removal or lowering of dams [Korpak and Lenar-Matyas 2019, Logar et al. 2005]. Despite the overall predominance of deposition, episodes of erosion still occur in the upstream section of the grade control system, as manifested in eroded crests and end sills as well as lowered channel bed relative to its position in 1986. The studied channel is gradually being lowered both in the area directly above and below the GCS. No scours were detected downstream of GCSs, as the channel bed is protected here by concrete stilling basins [Lenzi et al. 2003, Galia et al. 2016]. Probable cause for erosion is repair work on damaged riverbank reinforcements. In the course of such works, heavy equipment is used, which is also driven inside the channel. This leads to the destruction of depositional forms and the armored layer. Yet another reason for erosion is debris extraction by local residents. This is a permanent problem in this region, the pebbles are traditionally used for foundations and cladding of houses [Kościelniak 2004, Krzemień 2003]. Whenever the armor layer becomes disturbed, unprotected finer material enters the transport at lower flows, resulting in uncontrolled stages of erosion [Kondolf 1997].

Starting from GCS no. 8, successive GCSs constitute a barrier to the free transport of sediment. It is likely that transport does occur from time to time, as suggested by the presence of damaged crests. In this stretch of channel the main problem is lateral erosion, which threatens the 
same sites, even with frequent riverbank repairs. There is still a risk that the river will destroy the bank reinforcements and will flow outside the designated route, as it happened in 1983, during the course of regulation work. The river is not easy to "tame," as illustrated by the contract tender to remove flood damage in $\mathrm{km} \mathrm{1.595-2.700}$ (between GCSs no. 9 and 4), announced after the floods of May and June 2010. Reasoning provided in the tender implies that there exists a risk of the river bypassing the grade control system and following a new course.

Thus, the studied system of GCSs has not performed as intended - it did not provide vertical or horizontal stabilization of the channel or even a balance between erosion and deposition.

\section{CONCLUSIONS}

The studied channel section consisted of the downstream stretch of the Biały Dunajec River in the Polish Carpathian Mountains. The section was regulated 33 years ago using GCSs. A comparison of cross sections from 1986 and 2019 did not show any major changes. However, aerial photos and fieldwork data were used to show that the studied channel changes its morphology after every flood event. Each such event is followed by repair work, which helps restore the channel to its original regulation pathway shape.

The studied river has not adjusted to the parameters of the regulation pathway and is unstable. Each studied section of the channel is characterized by a predominance of one process over other processes. Sections 12 to 8 are characterized by deposition, sections 8 to 4 by lateral erosion, sections 4 to 2 by downcutting, and section 2 to the mouth of the river by deposition. The studied river continues to attempt to broaden its channel and increase its sinuosity. GCSs and bank reinforcements are damaged on a regular basis. Key problems with maintaining the regulation pathway appear at the same locations from year to year. Theoretically, the studied channel should be well maintained, given that a flood greater than the design discharge for this regulation happened only once in 1997. More research is needed in order to help understand why the studied river channel is not stable.

Research has shown that it is difficult to regulate a river such as the Biały Dunajec, with a high mountain regime and high variability of flows.
After 33 years the studied river is still attempting to increase its sinuosity and width. Repair work must be performed in the channel after even smaller flood events whose frequency has increased substantially in recent years. In the meantime, new investments are made along the river that need to be protected. Thus, this river section constantly generates large financial outlays for its maintenance.

\section{Acknowledgements}

This study was partially financed by the National Science Centre of Poland, research project No. 2018/02/X/ST10/02303.

\section{REFERENCES:}

1. Boix-Fayos C., Barberá G.G. López-Bermúdez F., Castillo V.M. 2007. Effect of check-dams, reforestation and land-use changes on river channel morphology: case study of the Rogativa catchment (Murcia, Spain). Geomorphology, 91, 103-123.

2. Fryirs K. 2013. (Dis)connectivity in catchment sediment cascades: a fresh look at the sediment delivery problem. Earth Surface Processes and Landforms, 38, 30-46.

3. Galia T., Hradecký J., Škarpich V., Přibyla Z. 2016. Effect of grade-control structures at various stages of their destruction on bed sediments and local channel parameters. Geomorphology, 253, 305-317.

4. Galia T., Škarpich V. 2017. Response of bed sediments on the grade-control structure management of a small piedmont stream. River Research and Applications, 33, 483-494.

5. Gaudio R., Marion A., Bovolin V. 2010. Morphological effects of bed sills in degrading rivers. Journal of Hydraulic Research, 38(2), 89-96.

6. Hajdukiewicz H., Wyżga B. 2019. Aerial photobased analysis of the hydromorphological changes of a mountain river over the last six decades: the Czarny Dunajec, Polish Carpathians. Science of the Total Environment, 648, 1598-1613.

7. Hess M. 1965. Piętra klimatyczne w polskich Karpatach Zachodnich. Zeszyty Naukowe UJ, Prace Geograficzne, 11, 1-258 (in Polish).

8. Klimaszewski M. 1972. Karpaty Wewnętrzne. In: M. Klimaszewski (ed.), Geomorfologia Polski, PWN, Warszawa (in Polish).

9. Kondolf G.M. 1997. Hungry water: effects of dam and gravel mining on river channels. Environmental Management, 21(4), 533-551.

10. Korpak J. 2015. Evolution of the lower Mszanka Channel section after training using stage correction 
method. Infrastruktura i ekologia terenów wiejskich, 4, 1285-1302.

11. Korpak J. 2018. Human impact on mountains streams and rivers. In: A. Radecki-Pawlik, S. Pagliara, J. Hradecký, E. Hendrickson (eds), Open channel hydraulics, river hydraulic structures and fluvial geomorphology: for engineers, geomorphologists and physical geographers. CRC Press Taylor \& Francis Group, Boca Raton, 400-435.

12. Korpak J., Lenar-Matyas A. 2019. Stream channel changes as a result of sudden sediment release due to check dam lowering (Polish Carpathians). Environmental Earth Sciences, 78, 404.

13. Korpak J., Lenar-Matyas A., Łapuszek M., Mączałowski A. 2019. Effect of riffle sequences on discharge and sediment transport in a mountain stream. Journal of Ecological Engineering, 20(3), 157-166.

14. Kościelniak J. 2004. Influence of river training on functioning of the Biały Dunajec River channel system. Geomorphologia Slovaca, 4(1), 62-67.

15. Krzemień K. 2003. The Czarny Dunajec River, Poland, as an example of human-induced development tendencies in a mountain river channel. Landform Analysis, 4, 57-64.

16. Lenzi M.A. 2002. Stream bed stabilization using boulder check dams that mimic step-pool morphology features in Northern Italy. Geomorphology, 45, 243-260.

17. Lenzi M.A., Marion A., Comiti F. 2003. Interference processes on scouring at bed sils. Earth Surface Processes and Landforms, 28, 99-110.

18. Logar J., Fifer Bizjak K., Kocevar M., Mikoš M., Ribicic M., Majes B. 2005. History and present state of the Slano Blato landslide. Nat. Hazards Earth Syst. Sci., 5, 447-457.

19. Marion A., Tregnaghi M., Tait M. 2006. Sediment supply and local scouring at bed sills in highgradient streams. Water Resorurces Research, 42, W06416.

20. Martín-Vide J.P., Andreatta A. 2009. Channel degradation and slope adjustment in steep streams controlled through bed sills. Earth Surface Processes and Landforms, 34, 38-47.
21. Piton G., Recking A. 2017. Effects of check dams on bed-load transport and steep-slope stream morphodynamics. Geomorphology, 291, 94-105.

22. Project No. 2220. 1969. Projekt wstępny - poszerzenie - ochrona Nowego Targu przed powodzią (in Polish).

23. Project No. 101. 1977. Regulacja Białego Dunajca w odcinku 0.000-3.260. Projekt techniczny (in Polish).

24. Project No. 4260. 1983. Porównawcza analiza techniczna uwzględniająca wykonane dotychczas roboty regulacyjne i zaistniałe zmiany w korycie Białego Dunajca w km 0.400-3.360 w stosunku do projektu technicznego. Hydroprojekt Oddział Kraków (in Polish).

25. Project No. 152. 1984. Ubezpieczenie brzegów pomiędzy stopniami na rzece Biały Dunajec od km 0.400 do 3.200. Projekt techniczny, Hydroprojekt Oddział Kraków (in Polish).

26. Projekt No. 4170. Inwentaryzacja powykonawcza korekcji stopniowej na potoku Biały Dunajec w km 0.900-3.266. Okręgowa Dyrekcja Gospodarki Wodnej w Krakowie (in Polish).

27. Project No. 2064. 2003. Usuwanie skutków powodzi z lipca 2001. Projekt budowlany regulacji koryta potoku Biały Dunajec w km 3.260-6.500 w miejscowości Szaflary. Hydroprojekt Oddział Kraków Sp. z o.o. (in Polish).

28. Radecki-Pawlik A. 2013a. The influence of a drophydraulic structure on the mountain stream channel regime - case study from the Polish Carpathians. Georeview, 23, 46-57.

29. Radecki-Pawlik A. 2013b. On using artificial rapid hydraulic structures (RHS) within mountain stream channels: some exploitation and hydraulic problems. In: P. Rowiński (ed.), Experimental and computational solutions of hydraulic problems. Springer, Berlin, Heidelberg, 104-115.

30. Wohl E. 2006. Human impacts to mountain streams. Geomorphology, 79, 217-248.

31. Wohl E., Lane S.N., Wilcox A.C. 2015. The science and practice of river restoration. Water Resources Research, 51(8), 5974-5997. 